\title{
Türkiye'de Acil Yıkım Yönetim Sistemi: Temel Yaklaşımlar, Elazı̆g Deprem Deneyimi Ve Öneriler
}

\author{
Bahattin Murat DEMİR ${ }^{1}$,Sami ERCAN ${ }^{2}$, Mustafa AKTAN ${ }^{3}$, Harun ÖZTAŞKIN ${ }^{4}$
}

\begin{abstract}
Özet
Ülkemizde yerleşim birimlerinde meydana gelen bir afet sonrasında karşılaşılan kamu sağlığı ve güvenliği riskleri arasında yapısal stabilitesini kaybeden binaların çökme riski öne çıkmaktadır. Ayrıca yapı stoğumuzun bir bölümü o derece düşük kalitededir ki, afet yaşanmadan da yapılar "yıkılacak derecede tehlikeli yapılar" haline gelebilmektedir. Afetlerin yerleşimler üzerindeki artan etkisine ve mevcut yapı stoğu kalitesine bağlı olarak ülkemizde acil yıkım ihtiyacı hızla artmaktadır. Ancak ülkemizde acil yıkım yeterince kavramsallaştırılmış ve yönetim modeli oluşturulmuş bir olgu değildir. Bu çalışmada öncelikle ülkemizdeki acil yıkım yönetim sisteminin ulusal mevzuatımıza nasıl yansıdığı kronolojik olarak incelenmiş; bu kapsamda rol üstlenen kurumlar ve izlenen usul ve şartlar ele alınmıștır. Bu bağlamda Elazığ depreminden çıkartılan dersler ile ulaşılan diğer veriler bütünleștirilerek acil yıkımın idari, teknik, çevresel ve sosyal boyutlarıyla bütüncül yönetimine yönelik öneriler geliştirilmeye çalışılmıștır. Ülkemizdeki acil yıkım yönetim sistemi, mevcut yaklaşımlarla, yeterli etkinlik, etkililik ve verimlilik noktasına ulaşamamış olup bu haliyle uzun vadede sürdürülebilir değildir.
\end{abstract}

Anahtar Kelimeler: Acil Yıkım, Afet Müdahale Planı, İdari İşlem, Yıkım Yönetimi

\section{Emergency Demolition Management System in Turkey: Basic Approaches, the Elazığ Earthquake Example and Suggestions}

\begin{abstract}
The risk of collapse of buildings that have lost their structural stability is the foremost public health and security risk that might be encountered following a natural disaster that takes place in a residential area. Moreover, some of Turkey's building stock is of such a low quality that, some buildings run the risk of entering the category of "buildings that may collapse" even without a precursor natural disaster. The need for swift demolition is increasing due not only to the

\footnotetext{
${ }^{1}$ Altyapı ve Kentsel Dönüşüm Hizmetleri Genel Müdürlüğü, Çevre ve Şehircilik Bakanlı̆̆ı Ankara

İlgili yazar e-posta/ Corresponding author e-mail: bmuratdemir@gmail.com ORCID No: 0000-0002-4300-0444

2 Mekansal Planlama Genel Müdürlüğü, Çevre ve Şehircilik Bakanlığı Ankara

e-posta/e-mail: samiercan0642@gmail.com ORCID No:0000-0001-9404-5952

3 Mekansal Planlama Genel Müdürlüğü, Çevre ve Şehircilik Bakanlığı Ankara

e-posta/e-mail: mustafa.aktan@csb.gov.tr ORCID No:0000-0001-8579-1136

${ }^{4}$ Çevre ve Şehircilik İl Müdürlügüu, Ankara Valiliği, Ankara

e-posta/e-mail: harunoztaskin@csb.gov.tr ORCID No: 0000-0002-1595-4507
}

Bu makaleye atıf yapmak için- To cite this article Demir, B. M., Ercan, S. Aktan, M. Ve Öztaşkın, H. (2020). Türkiye’de Acil Yıkım Yönetim Sistemi: Temel Yaklaşımlar, Elazığ Deprem Deneyimi Ve Öneriler. Afet ve Risk Dergisi, 3(2), 143-158. 
increasing effects of natural disasters on domiciles, but also to the quality of the building stock. Having said these, swift demolition is neither sufficiently conceptualized in Turkey, nor there exists a management model. In this study, the ways in which the emergency demolition system has been reflected unto national legislature has been investigated chronologically; and the stakeholding institutions and the rules and procedures have been examined. In this context, suggestions are proposed towards a comprehensive management, taking into account the administrative, technical, environmental and social aspects of emergency demolition and incorporating the lessons drawn from the Elazığ Earthquake and other data collected. The emergency demolition management system in Turkey with the current approach is insufficient in terms of effectiveness, efficiency and productivity and is unsustainable in the long run.

Keywords: Emergency Demolition, Disaster Response Plan, Administrative Action, Demolition Management

\section{GİRIŞ}

Ülkemiz merkezi ve yerel yönetimleri için en öncelikli konulardan biri de yerleşim birimlerini doğa ve insan kaynaklı afetlerin olumsuz etkilerine karşı koruyucu bir afet risk azaltımı ve yönetimi anlayışını hakim kılmak, afetlerden etkilenen yerleşimlerde ortaya çıkacak acil ihtiyaçları karşılamaya yönelik müdahale planlarını önceden geliştirebilmektir (URL 1). Özellikle deprem, sel, fırtına gibi ülkemizde geniş alanlarda etkili olan afetler, hem insanlar ve diğer canlılar hem de yapılı çevre için tehdit oluşturan göçme/çökme potansiyeli yüksek yapıların ortaya çıkmasına neden olmaktadır. Afet bölgesinde hayatın normalleșebilmesi için bu tür yapıların hızla tespitinin yapılarak yıkılması ve yıkım atıklarının kaldırılması; yaşam alanının hızla güvenli hale getirilmesi gerekmektedir. Afet müdahale sisteminde bu faaliyet, "acil yıkım" (emergency demolition) olarak nitelenir. Afet bölgesinde acil yıkımlar, arama kurtarma aşaması sonrasında devreye alınan, iyileşmeyi hızlandıran temel bir afet müdahale hizmetidir.

Acil yıkım ihtiyacının bir diğer kaynağını ise yaşam çevremizde yer alan ve yapım veya kullanım hataları sonucu göçme/çökme potansiyeli taşıyan yapılar oluşturur. İstanbul Kartal'da çöken Yeşilyurt Apartmanı gibi düşük kalite beton, statik proje hataları gibi yapısal olumsuzluklar ile Sütlüce'de kayan/göçen binada olduğu gibi dayanma yapısız derin kazı gibi yapılı çevrede gerçekleştirilen kontrolsüz girişimler nedeniyle herhangi bir afet yaşanmadan yapılar hasarlı hale gelmekte ve acil yıkım ihtiyacı ortaya çıkabilmektedir. Tehlike arz eden bu tür binaların öncelikle sahiplerince, sahipleri gereğini yapmaz ise ilgili İdarelerce yıkılması gerekmektedir. Bu kapsamdaki çalışmalar da tüm dünyada acil yıkım süreçlerinin bir parçası olarak kabul edilir.

Olguya bir bütün olarak bakıldığında, acil yıkım ihtiyacının ülkemizde geçmişe kıyasla hızlı bir şekilde büyüdügü görülür. Bu gerçekliğe karşın ülkemiz mevzuat ve bilimsel bilgi alt yapısında "acil yıkım" kavramı henüz yer almamaktadır. Mevcut afet ve imar hukuk sistemimizde "tehlikeli/ağır hasarlı binaların yıktırılması" konusunu düzenleyen mevzuat hükümleri ile karşılaşılsa da, konu idari ve hukuki bir sorun olmanın ötesine hiçbir zaman geçememiş; teknik, çevresel vb. boyutlarıyla bir bütünlük içerisinde ele alınmamıştır. Bu nedenle bugüne kadar ülkemizdeki acil yıkım hizmetinin niteliğini ve etkinliğini değerlendiren bilimsel bir araştırma da yapılmamıştır.

Ülkemizde bugüne kadar kavramsallaştırılmamıș olan "Acil Yıkım” (Emergency Demolition) özü itibariyle "herhangi bir afet veya acil durum (patlama, terör saldırısı vb.) sonrası gelișen hasarlar veya yapısal ve/veya zeminden kaynaklı bir sorun nedeniyle göçme/çökme tehlikesi altında olduğu yetkili kamu otoritesinin kararıyla tespit ve ilan edilen bir binanın kamu sağlığı ve güvenliği üzerinde yarattığı tehlikenin ortadan kaldırılması amacıyla yıktırılması ve yıkım atıklarının taşınması işlemidir". Bu kavramsal çerçeveden bakıldığında bir acil yıkım sürecinin diğer koşullardaki yıkımlara kıyasla daha yüksek oranda riskler içeren özel bir yıkım faaliyeti anlamına geldiği görülmektedir. Hangi gerekçeyle ve hangi idari süreçle alınmış olursa olsun "acil 
yıkım" kapsamına alınmış binalar yapısal stabilitelerini önemli oranda kaybetmiş, taşıyıcı sistemleri ağır hasarlı ve hatta kısmen yıkılmış, çatısı çökmüş; sonuç itibariyle sahip olduğu yapısal riskler nedeniyle her an istenmedik göçmelere/çökmelere eğilimli güvensiz yapılardır. $\mathrm{Bu}$ nedenle acil yıkımın oldukça hızlı bir șekilde kararlaștırılıp uygulanması gerekir. Zira kamu sağlığı ve güvenliği açısından bu derece yüksek riskli binaların yaşam çevresi içinde varlığını sürdürmesine izin verilemez; olumsuz bir durumla karşılaşmadan kamu güvenliğini korumak için hızlı hareket edilmesi; binaya müdahale edilerek, yıkılarak, kaldırılması gereklidir.

Yukarıda çizilen kavramsal çerçevede de vurgulandı ğı üzere acil yıkım, ancak ve sadece yetkili bir kamu otoritesinin yazılı idari kararına dayalı olarak gerçekleştirilen bir yıkım faaliyetidir. Acil yıkım ilanından uygulanmasına kadar her aşamasına ait iş ve işlemler, sadece ilgili İdareye tanınmış yetki çerçevesinde gerçekleştirilebilir. Herhangi bir kişi, örneğin bir bina sahibi, kendi kararıyla acil yıkım gerçekleştiremez. Acil yıkım sadece merkezi veya yerel kamu idarelerince tesis edilen bir yıkım anlamına gelir.

Diğer yandan acil yıkım sadece kentsel veya kırsal yerleşim alanlarında karşılaşılabilecek bina ve bina türü yapılar açısından ele alınması gereken bir konu değildir. Köprü, santral, fabrika gibi birçok kompleks yapılarda hasar alarak acil yıkım gerektiren yapı konumuna gelebilmektedir. 1999 depremlerinde bunun çok sayıda örneği ile karşılaşılmıştır. Bu çalışma bina ve bina türü yapılar dışındaki yapıların acil yıkımına yönelik süreçleri kapsamamaktadır. Her ne kadar mevzuat taraması sürecinde değinilmiş olsa da taşınmaz kültür varlıklarına yönelik acil yıkım süreçleri de bu çalışmanın dışında tutulmuştur.

\section{2. İDARİ İŞLEM BAĞLAMINDA ACİL YIKIM}

Dünyada acil yıkımın en temel karakteristiği, kamu gücü kullanılarak tesis edilen idari bir işlem olmasıdır (URL 2). Ülkemizde "kamu gücü kullanılarak idare işlevine yönelik olarak tesis edilen ve tek taraflı irade beyanıyla hukukî sonuç doğurabilen işlemler, doktrinde ve yargı kararlarında idari işlem olarak kabul edilmektedir" (URL 3). Yürürlükteki kamu hukuku açısından yıkım konusu, şartları yasa ve yönetmelikler ile düzenlenmiş bir idari işlem olarak değerlendirilmiş olup bu bağlamda acil yıkımlar da birer idari işlemdir (Ersöz, 2015). Bu nedenle bir acil yıkım işleminde aranması gereken ilk unsur; kamu gücü kullanılarak yani bir kanuna dayanılarak ve yetkilendirilmiş bir kamu idaresince tesis edilmiş olup olmadığıdır.

Ülkemizde "acil yıkım" kavramının belirli ve geçerli bir tanımı bugüne kadar ulusal mevzuatımızda yer almamıștır. Ancak adı konulmamış olsa da acil yıkım pratiği olarak kabul edilebilecek iş ve işlemlere dair birçok düzenleme bulunmaktadır. Konunun ulusal mevzuatımıza nasıl yansıdığını kronolojik olarak incelediğimiz mevzuat taraması çalışmamızda, bu konudaki mevzuat tarihçesinin 1940'lı yıllara kadar uzandı̆̆ı; 1940'lardan günümüze kadar geçen yaklaşık 80 ylllık tarihsel gelişim süreci içerisinde bu düzenlemelerin içeriğinde ciddi bir değişiklik meydana gelmediği görülmüștür. Kamu yönetimi açısından bu konu uzun yıllar, sadece hukuksal düzlemde ve nerdeyse aynı idari içerikte algılanmıștır.

Bugün itibariyle yürürlükte olan ve kamu hukuku açısından "acil yıkım" tanımına girebilecek işlemleri kapsayan düzenlemeler sahip olduğu idari işlem unsurları (yetki, usul vb. unsurlar) ile birlikte Tablo 1'de sunulmuştur. Tablo 1'den de görüldüğü üzere ülkemizde bu tür işlemlere ait usul ve şartlar farklı yasal düzenlemelere dağılmış durumdadır. Bu dağınık mevzuat altyapısının uygulamada çok başlılığa ve bazı sorunların yaşanmasına yol açması kaçınılmazdır. Tablonun yansıttığı bir diğer sonuç, ülkemizde yürürlükte olan adı konulmamış "acil yıkım yönetim süreçlerinin" belediyelerden daha çok merkezi yönetim organlarına dayandırılmış olmasıdır. Mevzuatımızda bu alana ilişkin olarak belediyelerin rolü azaltılmış ve belediyeler acil yıkım yönetimine katkı sunması beklenen yardımcı bir unsura dönüştürülmüştür. Oysa dünyada acil yıkım, nerdeyse tüm boyutlarıyla Belediyelerce gerçekleştirilen bir faaliyettir. 
Tablo 1. Ülkemizde Meri Mevzuatımızda Acil Yıkıma Yönelik Hükümlere Sahip Düzenlemeler İle Bu Düzenlemelerdeki Yetki, Usul vb. İdari İşlem Unsurları

\begin{tabular}{|c|c|c|c|c|c|c|c|}
\hline \multirow{3}{*}{$\begin{array}{l}\text { Düzenleme } \\
\text { Adı }\end{array}$} & \multirow{3}{*}{$\begin{array}{l}\text { Resmi } \\
\text { Gazete } \\
\text { (Tarih- } \\
\text { Sayı) }\end{array}$} & \multirow{3}{*}{$\begin{array}{l}\text { İlgili } \\
\text { Madde } \\
\text { numarası } \\
\text { ve Başlı̆̆ı }\end{array}$} & \multicolumn{5}{|c|}{ İzlenmesi Gereken Aşamalar } \\
\hline & & & \multicolumn{4}{|c|}{ Karar Alma Süreci } & \multirow[b]{2}{*}{ Yıkım } \\
\hline & & & $\begin{array}{l}\text { Dayanak } \\
\text { Rapor }\end{array}$ & $\begin{array}{l}\text { Yetkili } \\
\text { İdare }\end{array}$ & İlan & İtiraz & \\
\hline \multirow{2}{*}{$\begin{array}{l}6306 \text { Sayılı } \\
\text { Afet Riski } \\
\text { Altındaki } \\
\text { Alanların } \\
\text { Dönüștürülme } \\
\text { si Hakkında } \\
\text { Kanun }\end{array}$} & \multirow{2}{*}{$\begin{array}{l}31 / 05 / 20 \\
12-28309\end{array}$} & $\begin{array}{l}\text { "Tahliye ve } \\
\text { yıktırma" } \\
\text { Madde } 5\end{array}$ & $\begin{array}{l}\text { Riskli yapı } \\
\text { tespit raporu }\end{array}$ & ÇŞB & $\begin{array}{l}\text { Tapu } \\
\text { müdürlüğün } \\
\text { ce tebligat }\end{array}$ & $\begin{array}{l}\text { Tebligat } \\
\text { tarihinden } \\
\text { itibaren } 15 \\
\text { gün }\end{array}$ & $\begin{array}{l}\text {-Mal Sahibi -ÇŞB } \\
\text {-İlçe Belediyesi }\end{array}$ \\
\hline & & $\begin{array}{l}\text { "Uygulamaları } \\
\text { n resen } \\
\text { yapilması" } \\
\text { Madde 6/A } \\
\end{array}$ & $\begin{array}{l}\text { Riskli yapı } \\
\text { tespit raporu }\end{array}$ & ÇŞB & $\begin{array}{l}\text { Kapı ve } \\
\text { Muhtarlıkta } \\
2 \text { günlük ilan }\end{array}$ & $\begin{array}{l}\text { İki gün } \\
\text { içinde } \\
\text { itiraz } \\
\text { edilebilir }\end{array}$ & -ÇŞB \\
\hline $\begin{array}{l}\text { K..Y.K. } \\
\text { Yönetmeliği } 1\end{array}$ & $\begin{array}{l}18 / 02 / 20 \\
12-28208\end{array}$ & $\begin{array}{l}\text { "Zorunlu devir } \\
\text { ve yıkım" } \\
\text { Madde } 13\end{array}$ & \multicolumn{5}{|c|}{$\begin{array}{l}\text { "Çevreye zarar verme ihtimali resmi kurum raporu ile saptanan” ve "acil } \\
\text { yıkılması gereken" kurum binaları "Genel Müdürün onayı ile yıktırılır". }\end{array}$} \\
\hline $\begin{array}{l}\text { Koruma } \\
\text { Büroları } \\
\text { Yönetmeliği² }\end{array}$ & $\begin{array}{c}11.06 .2005 \\
-25842\end{array}$ & $\begin{array}{l}\text { "Koruma, } \\
\text { uygulama ve } \\
\text { denetim } \\
\text { bürolarının } \\
\text { görevleri" } \\
\text { Madde } 7\end{array}$ & \multicolumn{5}{|c|}{$\begin{array}{l}\text { Acil yıkımın idari işlem süreçlerine ilişkin doğrudan hükümlere sahip değil. } \\
\text { Koruma, uygulama ve denetim bürolarının görevleri arasında "Tescilli kültür } \\
\text { varlıklarının mail-i inhidam olmaları halinde can ve mal güvenliğinin sağlanması } \\
\text { için gerekli işlemleri yaparak durumu koruma bölge kurulu müdürlüğüne } \\
\text { iletmek" tanımlanmıştır. }\end{array}$} \\
\hline $\begin{array}{l}5216 \text { Sayılı } \\
\text { Büyükșehir } \\
\text { Belediyesi } \\
\text { Kanunu }\end{array}$ & $\begin{array}{l}23 / 07 / 20 \\
04-25531\end{array}$ & $\begin{array}{l}\text { "Büyükşehir ve } \\
\text { ilçe } \\
\text { belediyelerinin } \\
\text { görev ve } \\
\text { sorumlulukları } \\
\text { " Madde } 7 \\
\end{array}$ & \multicolumn{5}{|c|}{$\begin{array}{l}\text { Acil yıkımın idari işlem süreçlerine ilişkin doğrudan hükümlere sahip değil. } \\
\text { Ancak "Afet riski taşıyan veya can ve mal güvenliği açısından tehlike oluşturan } \\
\text { binaları tahliye etmek ve yıkmak (İlçe Belediyesi görev ve yetkileri)"; yıkım } \\
\text { konusunda ilçe belediyelerinin talepleri hâlinde her türlü desteği sağlamak } \\
\text { (Büyükşehir belediyesinin görev, yetki ve sorumlulukları) }\end{array}$} \\
\hline $\begin{array}{l}3194 \text { Sayılı } \\
\text { İmar Kanunu }\end{array}$ & $\begin{array}{l}09 / 05 / 19 \\
85-18749\end{array}$ & $\begin{array}{l}\text { "Yıkılacak } \\
\text { derecede } \\
\text { tehlikeli } \\
\text { yapılar" } \\
\text { Madde } 39\end{array}$ & $\begin{array}{l}\text { Dayanak } \\
\text { rapor } \\
\text { tanımsı; } \\
\text { tespit } \\
\text { işlemine } \\
\text { vurgu } \\
\text { yapilmış }\end{array}$ & $\begin{array}{c}\text { Metruk } \\
\text { bina tespiti } \\
\text { anlaminda } \\
\text { Valilik; } \\
\text { ylkılacak } \\
\text { derecede } \\
\text { tehlikelilik } \\
\text { tespiti } \\
\text { anlaminda } \\
\text { Valilik ve } \\
\text { Belediye } \\
\end{array}$ & $\begin{array}{l}\text { İlgili } \\
\text { idarenin } \\
\text { internet } \\
\text { sayfasında } \\
30 \text { günlük } \\
\quad \text { ilan }\end{array}$ & Tanımsız & $\begin{array}{l}\text {-Mal Sahibi } \\
\text {-Valilik } \\
\text {-Belediye }\end{array}$ \\
\hline $\begin{array}{l}2935 \text { Sayılı } \\
\text { Olağanüstü Hal } \\
\text { Kanunu }\end{array}$ & $\begin{array}{l}27 / 10 / 19 \\
83-18204\end{array}$ & $\begin{array}{l}\text { "Alınacak } \\
\text { tedbirler" } \\
\text { Madde } 9\end{array}$ & \multicolumn{4}{|c|}{$\begin{array}{l}\text { Acil yıkımın idari işlem süreçlerine ilişkin doğrudan } \\
\text { hükümlere sahip değil. Ancak "Tabii afet ve tehlikeli salgın } \\
\text { hastalıklar sebebiyle olağanüstü hal ilanında", "yazılı } \\
\text { tedbir" olarak "Tehlike arz eden binaların yıkım”"ına imkan } \\
\text { veren bir düzenleme }\end{array}$} & $\begin{array}{l}\text { OHAL } \\
\text { kapsamındaki } \\
\text {-Bölge Valisi } \\
\text {-İl Valisi }\end{array}$ \\
\hline \multirow{3}{*}{$\begin{array}{l}7269 \text { Sayılı } \\
\text { Umumi Hayata } \\
\text { Müessir Afetler } \\
\text { Dolayısıyla } \\
\text { Alınacak } \\
\text { Tedbirlerle } \\
\text { Yapılacak } \\
\text { Yardımlara } \\
\text { Dair Kanun }{ }^{3}\end{array}$} & \multirow{3}{*}{$\begin{array}{l}25 / 05 / 19 \\
59-10213\end{array}$} & Madde 3 & \multicolumn{4}{|c|}{$\begin{array}{l}\text { Dayanak rapor tanımsız; tespit işlemine vurgu yapılmış. } \\
\text { Verilen } 3 \text { aylık süre içinde tehlikeli durumun giderilmesi } \\
\text { şeklinde düzenleme }\end{array}$} & $\begin{array}{l}\text { Valilik } \\
\text { Kaymakamlık } \\
\text { Belediye }\end{array}$ \\
\hline & & $\begin{array}{l}\text { "Afet } \\
\text { bölgelerinde } \\
\text { yapilacak } \\
\text { teknik işler" } \\
\text { Madde 13 }\end{array}$ & $\begin{array}{l}\text { En büyük } \\
\text { mülki } \\
\text { amirine ayrı } \\
\text { bir rapor } \\
\text { verilir }\end{array}$ & $\begin{array}{l}\text { Valilik } \\
\text { Kaymakam } \\
\text { lık }\end{array}$ & $\begin{array}{l}\text { En çok } 3 \\
\text { günlük } \\
\text { sürelik ilan }\end{array}$ & \begin{tabular}{|l|} 
Bu \\
bildiriye \\
karşı 3 gün \\
içinde \\
itiraz \\
edebilir \\
\end{tabular} & $\begin{array}{l}\text { Valilik } \\
\text { Kaymakamlık }\end{array}$ \\
\hline & & Madde 14 & \multicolumn{2}{|c|}{$\begin{array}{l}\text { Dayanak rapor tanımsız } \\
\text { ancak düzenlemeden "Yapı } \\
\text { ve ikamet için yasaklanmış } \\
\text { afet bölgesi" kararına esas } \\
\text { Jeolojik Etüt Raporu olduğu } \\
\text { anlaşıllyor. }\end{array}$} & \multicolumn{2}{|c|}{$\begin{array}{l}\text { Raporun afet mahallinde } \\
\text { askıya çılkartılması } \\
\text { sözkonusu. Askı işlemi } \\
\text { sırasında itiraz yapılabiliyor }\end{array}$} & $\begin{array}{l}\text { Valilik } \\
\text { Kaymakamlık }\end{array}$ \\
\hline
\end{tabular}

(1Yüksek Öğrenim Kredi Ve Yurtlar Kurumu Tarafından Taşınmaz Satın Alınması, Satılması, Trampa Yapılması, Irtifak Hakkı Ve Benzeri Ayni Nitelikteki Hakların Tesisi İle Taşınmaz Kiralanması Ve Kiraya Verilmesi Hakkında Yönetmelik; ${ }^{2}$ Koruma, Uygulama Ve Denetim Büroları, Proje Büroları İle Eğitim Birimlerinin Kuruluş, İzin, Çalışma Usul Ve Esaslarına Dair Yönetmelik; ${ }^{35902 ~ s a y ı l ı ~ y a s a ~ g e r e g ̆ i n c e ~}$ 7269 sayılı yasada Imar ve İskan Bakanlığına yapılan atıflar AFAD Başkanlığına yapılmış sayılmaktadır.) 


\section{BİR AFET YÖNETIM FONKSIYYNU OLARAK ACILL YIKIM}

AFAD Başkanlığı tarafından yayınlanan Açıklamalı Afet Yönetim Terimleri Sözlüğü’nde (URL 4) bir afet veya acil durumun yaşanmasından sonra afet/acil durum bölgesinde gerçekleștirilen arama ve kurtarma, sağlık, iașe, ibate, güvenlik, mal ve çevre koruma, sosyal ve psikolojik destek hizmetleri afet müdahale faaliyetleri olarak tanımlanmaktadır. Afet yönetim sisteminin önemli bir aşamasını olușturan müdahale evresindeki bu faaliyetlerin amacı; mümkün olan en kısa süre içinde çok sayıda insanın hayatını kurtarmak, yaralıların ilk yardım ve tedavilerini gerçekleștirmek, geçici barınma, yiyecek vb. gereksinimlerini karșılamak, meydana gelen hasarın tespitini yapmak, yaşam çevresinde tehlike oluşturan bina ve enkazlarını kaldırılmaktır. Böylece, afet nedeniyle bozulan yaşam şartlarının normalleștirilmesine yönelik en uygun koşulların oluşturulması hedeflenir.

Bozulan yaşam şartlarının normalleștirilmesi sürecinin bir parçası da afet/acil durum bölgesinde hasar görmüș ve tehlike arz eden tüm yapıların yıkılması ve olușan yıkım atıklarının kaldırılmasıdır. Acil yıkım, afet müdahale hizmetlerinin icrasında özel ve öncelikli bir uygulama alanını oluşturur. Acil yıkımın amacı, çökme/göçme riski taşıyan binaların hızla yıkılarak atıklarının kaldırılması yoluyla hem diğer müdahale faaliyetleri hem de daha sonraki evreye ait iyileștirme faaliyetleri için güvenli bir ortamın oluşturulmasıdır. Afet/acil durum bölgesindeki müdahale sürecinin başlangıcında gerçekleştirilen ilk faaliyet, doğal olarak, arama ve kurtarma faaliyetidir. Arama ve kurtarma çalışmalarının tamamlandığının ilanı ile birlikte acil yıkım faaliyetlerinin uygulanmasına geçilir. Aslında arama-kurtarma ve acil yıkım aşamaları arasında keskin bir sınır bulunmaz; çünkü birçok arama-kurtarma noktasında ekiplerin çalışmalarını kolaylaştırabilmek amacıyla yıkıntı bloklarını desteklemek veya askıya almak, yıkıntı enkazı kaldırmak gibi çalışmalar için acil yıkım firmaları devreye girerler.

Ülkemizde Cumhuriyet döneminde oluşturulan afet hukukunda hasarlı bina yıkım işlemlerinin özel olarak düzenlenmeye çalışıldığı görülmektedir. 1944 yılında yürürlüğe giren ve Cumhuriyet tarihinin ilk Afet Yasası olarak kabul edilen 4623 sayılı Yersarsıntısından Evvel ve Sonra Alınacak Tedbirler Hakkında Kanun'un (YESATHK) 9uncu maddesinde "Yersarsıntısını müteakip Nafia Vekâletince kurulacak fen heyetleri tarafından resmî ve hususi bütün binalar tetkik ve muayeneye tabi tutulur. Bunlardan yıktırılması ve boşaltılması gerekenler hakkında fen heyetlerince mahallin mülkîye âmirine rapor verilir. Bu makamlarca bu binalar derhal boşaltılır. Yıkılması icabedenler için en çok 15 gün mühlet verilerek tehlikenin giderilmesi sahiplerine bildirilir. Mahallinde sahibi bulunmadığı takdirde keyfiyet mahallî vasıtalarla ilân edilmek suretiyle tebliğ yapılmış sayılır. Mal sahibi yıkmadığı takdirde bu binalar, yıkma parası yıkıntı bedelinden ödenmek üzere mahallin mülkiye âmirinin emriyle yıktırılır" șeklinde bir hükme yer verilmiştir (YESATHK, Madde 9). Halen yürürlükte olan 7269 sayılı Umumi Hayata Müessir Afetler Dolayısıyla Alınacak Tedbirlerle Yapılacak Yardımlara Dair Kanun'un (URL 5) 13üncü maddesinde de “...Arazinin tehlikeli durumu ve binaların gördüğ̈̈ hasar bakımından yıktırılması ve boșaltılması gerekenler hakkında, o il ve ilçenin en büyük mülkiye amirine ayrı bir rapor verilir. Bu makamlarca böyle binalar derhal boşalttırılır. Yıkılması gerekenler için en çok 3 gün süre verilerek tehlikenin giderilmesi sahiplerine bildirilir. Mahallinde sahibi bulunmadiğı takdirde durum, mahalli vasıtalarla ilan edilmek suretiyle, bildiri yapılmış sayılır. Mal sahibi veya vekili, bu bildiriye karşı 3 gün içinde yetkili idare kurullarına itiraz edebilir. İdare kurulları bu itirazı en geç 3 gün içinde inceler ve karara bağlar" hükmü yer almaktadır. Görüldüğü üzere bu konudaki hüküm yaklaşık 80 yıldır nerdeyse aynı içerikte uygulanmıştır. Meri mevzuatta afet hukuku bağlamında gerçekleştirilen acil yıkımlar 7269 sayılı Kanun'un 3üncü, 13üncü ve 14üncü maddelerinde düzenlenmiş olup bu yıkımlar hem tekil bina hem de alan ("yapı ve ikamet için yasaklanmış afet bölgesi") bazındadır (Tablo 1). 
Afet hukukunda kanun düzeyi dışındaki mevzuatta da acil yıkım üzerine gerçekleştirilmiş düzenlemeler söz konusudur. "Afetlere İlişkin Acil Yardım Teşkilâtı ve Programları Hakkında Yönetmelik (1968)" ile başlayan süreçte 1988 yılında yayımlanan "Afetlere ilişkin Acil Yardım Teşkilatı ve Planlama Esaslarına Dair Yönetmelik (1988)" ile "afetzede vatandaşlara en etkin ilk ve acil yardım yapılmasını sağlamak için acil yardım teşkilatlarının kuruluş ve görevleri" yeniden düzenlenmiştir. Mezkur Yönetmelik ile oluşturulan "Ön Hasar Tespit ve Geçici İskân Hizmetleri Grubuna" "can güvenliği bakımından oturulması sakıncalı olan ve yıktırılması gereken binaları belirlemek"; "Kurtarma ve Yıkıntıları Kaldırma Hizmetleri Grubuna" "kurtarma ve yardım çalışmaları bakımından tehlikeli olabilecek binaların desteklenmesi, yıkılması ve temizlenmesini sağlamak"; Mülga Bayındırlık ve İskan Bakanlığına ise "hasar tespit sonuçlarına göre can ve mal kaybına neden olabilecek yıktırılması gereken binalara ait raporları düzenlemek ve ilgililere bildirmek" gibi somut görev ve sorumluluk verilmiştir. 2013 yılında yürürlüğe giren "Afet ve Acil Durum Müdahale Hizmetleri Yönetmeliği" (URL 6) ile yeni bir "Ulusal Afet Müdahale Sistemi" dönemine geçilmiş ve "Türkiye Afet Müdahale Planı (TAMP)" ile acil yıkım ve diğer müdahale hizmetleri, bu hizmetleri yerine getirecek müdahale hizmet grupları ve ana çözüm ortağı Bakanlıklar yeniden düzenlenmiştir. Tablo 2'den görüldüğü üzere "Türkiye Afet Müdahale Planı (TAMP)", ülkemiz acil yıkım mevzuat tarihçesinde özgün bir yere sahiptir. TAMP içerdiği "acil yıktırılması gereken binaları tespit etmek" ibaresiyle "acil yıkım" kavramına yer veren ilk ve tek mevzuat olma özelliğini taşımaktadır. Diğer yandan Plan, acil yıkım operasyonlarının "tespit" ve "yıkım" süreçlerini daha net çizgilerle birbirinden ayırarak, bu görevleri farklı hizmet gruplarına tanımlamıştır (Tablo 2). Ancak görüldügü gibi bu hizmet gruplarına, acil yıkım hizmetinin bütünlüğü açısından olması gereken personel ve iş makinaları ile bilgi sistemleri fonksiyonlarına dair herhangi bir görev ve sorumluluk tanımlaması yapılmamıştır.

Tablo 2. TAMP'nda Acil Yıkım Kapsamında Faaliyetleri Üstlenen Hizmet Grupları, Ana Çözüm Ortakları ve Üstlendikleri Görev Sorumluluklar (URL 7).

\begin{tabular}{|l|l|l|}
\hline $\begin{array}{l}\text { HİZMET } \\
\text { GRUBU }\end{array}$ & $\begin{array}{l}\text { ANA ÇÖZÜM } \\
\text { ORTAGI }\end{array}$ & HİMET GRUBUNUN GÖREV VE SORUMLULUKLARI \\
\hline $\begin{array}{l}\text { Hasar Tespit } \\
\text { Hizmet } \\
\text { Grubu }\end{array}$ & $\begin{array}{l}\text { Çevre Ve Şehircilik } \\
\text { Bakanlığı }\end{array}$ & $\begin{array}{l}\text {-Afet bölgesinde alt yapı (su, kanalizasyon, arıtma vb.) ve yapı } \\
\text { stokunda meydana gelen yaklaşı ön hasar boyutunu ivedilikle } \\
\text { belirlemek ve üst makamları bilgilendirmek. } \\
\text {-Bina, altyapı (su, kanalizasyon, arıtma vb.) ve kritik tesislerin } \\
\text { hasar tespitini yapmak, yaptırmak. } \\
\text {-Acil yıktırılması gereken binaları tespit etmek. }\end{array}$ \\
\hline $\begin{array}{l}\text { Enkaz } \\
\text { Kaldırma } \\
\text { Hizmet } \\
\text { Grubu }\end{array}$ & $\begin{array}{l}\text { Çevre Ve Şehircilik } \\
\text { Bakanlığı }\end{array}$ & $\begin{array}{l}\text {-Enkaz döküm alanlarını belirlemek. } \\
\text {-Arama ve kurtarma çalışmaları bittikten sonra bina, tesisler ve } \\
\text { çevi enkazın kaldırılmasını sağlamak. } \\
\text {-Ylkılması gereken hasarlı binaların yıkılması, yıktırılması ve } \\
\text { enkazın kaldırılmasını sağlamak. }\end{array}$ \\
\hline
\end{tabular}

Acil yıkım her ne kadar afet/acil durum sonrası müdahale evresinde icra edilen bir faaliyet olsa da afet/acil durum öncesine ait fonksiyonların icra edildiği hazırlık evresiyle de doğrudan ilgilidir. Afet yönetim sisteminde hazırlık, afetlere hızlı ve etkili olarak müdahale edebilmek için afet öncesinde yapılması gereken planlama, eğitim, tatbikat, bilgilendirme gibi faaliyetlerin yürütüldügü bir evre olarak tanımlanmaktadır (URL 4). Tüm müdahale faaliyetlerinde olduğu gibi acil yıkımların da en etkin ve verimli bir şekilde yapılmasını sağlamak amacıyla göreve en uygun organizasyonların belirlenmesi, personel eğitimleri vb. önlemlerin önceden alınması gerekmektedir. Acil yıkımla ilgili hazırlıklar afet/acil durumlar karşısında hazırlık kapasitesinin artırılmasına yönelik çalışmaların bir bileşenidir. Sonuç itibariyle acil yıkım olgusu, afet/acil 
durum yönetim sisteminin afetlere/acil durumlara hazırlı ve müdahale kapasitesinin geliştirilmesi ve toplumun dirençli hale gelmesiyle doğrudan ilgili bir olgudur.

\section{IMMAR HUKUKUNDA ACİL YIKIM}

Ülkemizde acil yıkım konusunun düzenlendiği bir diğer hukuksal alan, imar hukukudur. 1930'lu yıllardan bugüne kadar İmar ve șehirleşme süreçlerini yönlendirmek üzere hazırlanan mevzuatta, afet mevzuatında olduğu gibi, adı konulmamış "acil yıkım" düzenlemeleriyle karşılaşmak mümkündür. Bu düzenlemeler acil yıkım konusunu, basit ve tekdüze gözlemsel incelemelere dayalı idari bir işlem olarak ele almıştır. Dolayısıyla bu haliyle mevcut düzenlemelerin, nüfus ve yapılaşmanın yoğunlaştığı günümüz kentlerinde gerçekleştirilecek acil yıkım faaliyetlerindeki gereksinimleri karşılaması mevcut haliyle mümkün gözükmemektedir.

1580 sayılı Belediye Kanunu (1930)'ndaki (URL 8) "kazalı binaları ve baca ve duvarları yıktırmak"; 2290 sayılı Belediye Yapı Ve Yollar Kanunu (1933)'ndaki (URL 9) "yıkılacak halde bulunan ve imarı kabil olmayan bırakılmış binalar veya duvarlar belediyeler tarafından belediye encümeni kararı ile hemen yıktırılacaktır" şeklindeki düzenlemeler Cumhuriyet döneminde acil yıkım işlemlerine yönelik olarak gerçekleştirilmiş ilk mevzuat örnekleri olarak karşımıza çıkmaktadır. Bu konuda en iyi bilinen düzenleme ise TBMM'nde kabul edildiği 1956 yılından sonra yaklaşık 30 yıl yürürlükte kalan 6785 sayılı İmar Kanunundaki "bir kısmı veya tamamı yıkılacak derecede tehlikeli olduğu, belediye fen heyeti, yoksa fen adamı tarafından raporla tesbit edilen yerlerin mal sahibi tarafından tamir edilerek veya yıktırılarak tehlike ortadan kaldırılmazsa, belediye encümeni kararıyla yıktırılır. Alâkalının fakrıhali tevsik olunursa masraf belediye bütçesinden karşılanır. Tehlike durumu o yerin ve civarının boşaltılmasını icap ettiriyorsa, hüküm istihsaline hacet kalmaksızın zabıta marifetiyle bina ve civarı derhal tahliye ettirilir" şeklindeki düzenlemedir (İmar Kanunu-6785 Md:50, URL 10).

1985 Yılından beri yürürlükte olan 3194 sayılı İmar Kanununda da (URL 11), 6785 sayılı Kanun'dakine benzer içerikte hükümler yer almaktadır. Örneğin son hali 2109 yılında verilen "Yıkılacak derecede tehlikeli yapılar" başlıklı 39uncu maddesinde "Genel güvenlik ve asayiş bakımından tehlike arz ettiği valilikçe tespit edilen metruk yapılar ile bir kısmı veya tamamının yıkılacak derecede tehlikeli olduğu belediye veya valilik tarafından tespit edilen yapıların" yıkım işleminin usul ve şartları belirtilmiştir. 3194-39'uncu maddesinde yer alan hüküm, tekil bina ölçeğindeki acil yıkım uygulanmalarına yönelik bir düzenlemedir.

İmar mevzuatı ve acil yıkım denilince Belediyelerimizde ve kamuoyunda akla ilk gelen kavramlardan biri "maili inhidam (çökme eğilimli) yapı" diğeri ise "metruk (harabe) yapı" kavramlarıdır. Mevzuat taraması çalışmamızda her iki kavram üzerine İçişleri Bakanlığınca hazırlanmış düzenlemelerle karşılaşılmıştır. 1969 yılında İçişleri Bakanlığınca yayımlanan Belediye Zabıta Personeli Yönetmeliği ile zabıtaya verilene "maili inhidam binaların boşaltılması ve yıktırılması hallerinde belediyenin fen ve sağlık kuruluşlarının yetkili elemanlarına yardımcı olmak" görevi 2007 yılında İçişleri Bakanlığınca yayınlanan, daha sonra yürütmesi Çevre ve Şehircilik Bakanlığına geçen, Belediye Zabıta Yönetmeliğinde "yıkılacak derecedeki binaları boşalttırmak, yıkım kararlarının uygulanmasında gerekli tedbirleri almak, ruhsatsız yapılan inşaatları tespit etmek ve derhal inşaatı durdurarak belediyenin fen kuruluşlarının yetkili elemanlarıyla birlikte tutanak düzenlemek" șeklinde bugün de devam ettirilmiștir (URL 12, Md7; URL 13, Md10).

Günümüzde "metruk" kavramı meri imar ve kentsel dönüşüm mevzuatı dışında İçişleri Bakanlığınca hazırlanmış ve içeriğinde bu tür binaların yıkımına yönelik yaklaşımların yer aldığı genelgelerde de karşımıza çıkabilmektedir ( 27.06.2016 ve 14.03.2018 tarihli genelgeler gibi). Yaşam çevresinde metruk binaların varlığı kamu güvenliği açısından bir risk unsuru olarak kabul edilmektedir. 


\section{KENTSEL DÖNÜŞÜM VE ACİL YIKIM}

Özellikle son dönemde acil yıkım konusu aynı zamanda bir kentsel dönüşüm faaliyeti olarak da karşımıza çıkmaktadır. Yürürlüğe girdiği 2012 yılından itibaren sık sık kamuoyu gündeminde gelen 6306 sayılı Afet Riski Altındaki Alanların Dönüştürülmesi Hakkında Kanun "sağlıklı ve güvenli yaşama çevrelerini teşkil etmek" üzere "riskli yapıların" tasfiyesine yönelik iş ve işlemleri düzenlemekte olup bu iş ve işlemler doğrudan acil yıkım alanına girebilecek niteliktedir (URL 14, Md. 1). Mezkur Kanunun kamuoyunda en bilinen kavramı olan "riskli yapı", özünden acil yıkım gerektirecek derecede tehlikelere sahip bir yapıyı çağrıștırsa da her zaman bu nitelikte bir yapı söz konusu değildir. Ancak Kanuna 2019 yılında eklenen "Uygulamaların resen yapılması" başlıklı "6/A Madde" ile Çevre ve Şehircilik Bakanlığına verilen "yıkılacak derecede riskli olan yapıların bulunduğu alanlar ile kendiliğinden çöken veya zeminin kayması, heyelan, su baskını, kaya düşmesi, yangın, patlama gibi sebeplerle ağır hasar gören veya ağır hasar görme riski bulunan yapıların bulunduğu alanlarda" tahliye ve yıktırmaya yönelik yetkiler açıktır ki acil yıkım şart ve koşullarını ifade etmektedir.

Bu madde kapsamında gerçekleştirilecek işlemler için öncelikle yapının "riskli yapı" tespitinin yapılması gereklidir. "Riskli olarak tespit edilen yapıların listesi tebliğ yerine kaim olmak üzere, bu yapıların kapısına asılır ve ilgili muhtarlıkta iki gün süre ile ilan edilir. Riskli yapı tespiti işlemi bu ilan ile maliklere şahsen tebliğ edilmiş sayılır. Riskli yapı tespitlerine karşı maliklerce veya kanuni temsilcilerince iki gün içinde itiraz edilebilir ve itirazlar üç gün içerisinde teknik heyetler tarafından incelenip karara bağlanır" (URL 14, Md. 6/A).

Çevre ve Şehircilik Bakanlığı bu maddeye dayanarak İstanbul Kartal'da ve Elazığ Depreminde olduğu gibi birçok yerleşim biriminde acil yıkım uygulamaları gerçekleştirmiştir. 6/A Maddesinin eklenmesiyle birlikte 6306 sayılı Kanun, ulusal acil yıkım yönetim sisteminin en yeni, aynı zamanda da en etkin mevzuatı haline gelmiștir. Öncelikle mezkur madde ile afet ve imar hukukunda acil yıkım kapsamında ayrı ayrı kullanılan yetki ve sorumluluklar bir bütün halinde 6306 kapsamına alınarak Çevre ve Şehircilik Bakanlığı yetkili kılınmıştır. İkincisi ise bu düzenleme ile acil yıkımların hem tekil yapı ("riskli yapı") hem de alan ("riskli alan", "yıkılacak derecede riskli olan yapıların bulunduğu alanlar") ölçeğinde yapılabilmesine imkan yaratılmıştır. Dolayısıyla ülkemizde önümüzdeki günlerde gerçekleştirilecek acil yıkımlarda diğer mevzuata kıyasla 6306 sayılı Kanunun ön plana çıkması beklenmektedir.

\section{TEKNIKK BOYUTLARIYLA ACİL YIKIM YÖNETIMİ}

Yaşam çevremizdeki yapılar kullanım süresinde statik ve dinamik birçok etkiye maruz kalırlar. Bu etkiler deprem, heyelan, yangın vb. afetlerden kaynaklanabildiği gibi yapım veya kullanım aşamasında meydana gelen hatalardan (proje hataları, yanlış yapı malzemesi, inşaat sonrası kontrolsüz müdahaleler vb.) kaynaklanabilir. Bu etkiler yapının taşıyıcı olan ve/veya olmayan kısımlarında bazı deformasyon ve dayanım kayıplarına yol açar. Bu deformasyon ve kayıpların kabul edilebilecek sınırları aşması halinde ise yapı hasarlı hale geçer ki yapıda ikamet veya diğer amaçlarla kullanımı riskli hale gelir. Bu durumda güçlendirme ve onarımlarla yapıda öngörülen güvenlik seviyesine ulaşmak mümkün değil ise bu konumdaki yapıların kamu sağlığı ve güvenliği açısından acil yıkımlarının gerçekleştirilmesi ve yaşam çevresinden kaldırılması gereklidir.

\subsection{Acil Yıkım Sürecinde Raporlama}

Her acil yıkım işlemi için işleme dayanak oluşturacak teknik bir raporun düzenlenmiş olması öncelikli ve temel bir koşuldur. Yetkili İdareler böylesi bir raporu dayanak tutmadan işlem tesis edemezler. Bir yapının acil yıkım gerektirip gerektirmediğini belirleme yeteneği sadece bu raporlarda mevcuttur. Bu raporlar hazırlanmadan süreç başlayamayacağ gibi sürecin izlemesi ve denetimi de mümkün olamamaktadır. Dolayısıyla bu raporlarda yapıdaki hasar noktaları ve 
derecesi, yapının tehlikeli malzeme içerip içermediği, jeolojik koşul ve riskler (yeraltı su seviyesi, heyelan vb.), yıkımın yapılı çevre içerisinde diğer binalarla ve parsellerle etkileşimi gibi konuların irdelenmesi gerekir. Raporlar mahallinde düzenlenmiş olmalı ve açık bir şekilde kamu sağlığı ve güvenliği açısından yıkım işleminin gerekli görüldügünün belirtilmelidir. Öte yandan İdari yargılamada, özellikle yıkım kararları sonucu ortaya çıkan durumlar için imar hukuku açısından mahkemelerce verilecek kararlarda "maili inhidam raporunun" düzenlenerek durumun raporla saptanmış olması temel bir gereklilik olarak aranmaktadır (URL 15).

Acil yıkım yönetimi için başlangıç noktası olan bu raporlar sahip olduğu önemine ve ülkemiz mevzuatında kendisine atıflar yapılmış olmasına karşın bugüne kadar formatına ve içeriğine yönelik herhangi bir düzenleme yapılmamıștır. Örneğin İmar Kanununda belirtilen ve "maili inhidam raporları" olarak da bilinen raporlar Belediye teknik personeli ve zabıtası tarafından düzenlenmekte olup uygulamada, "tutanak" formatında, gözlemsel tespitleri içeren kısa ve öz ifadeler taşıyan bir belge niteliğindedir.

7269 sayılı Yasanın 13üncü maddesi gereğince "arazinin tehlikeli durumu ve binaların gördüğü hasar bakımından yıktırılması ve boşaltılması gerekenler hakkında" düzenlenecek raporlar ise afetin türüne göre değişmekte olup heyelan, su baskını vb. afetler için jeolojik etüt; deprem afetinde ise hasar tespit raporu niteliğindedir. Bu raporlar afetin meydana geldiği il ve ilçenin en büyük mülki amirine verilerek acil yıkım süreci başlatılmaktadır.

Acil yıkım için ulusal mevzuatımızda düzenlenmiş bir diğer raporlama işlemi, korunması gerekli taşınmaz kültür varlıklarının "mail-i inhidam olmaları halinde" yürütülecek işlemlere yöneliktir. Koruma, Uygulama Ve Denetim Büroları, Proje Büroları İle Eğitim Birimlerinin Kuruluş, İzin, Çalışma Usul Ve Esaslarına Dair Yönetmelik'e istinaden, çevresi için tehlike yaratan taşınmaz kültür varlıkları için Koruma, Uygulama Ve Denetim Bürolarınca yapılacak maili inhidam tespitinin Koruma Kurullarına iletilmesi ve Kurulun vereceği karara göre hareket edilmesi gerekmektedir (URL 16, Md. 7). Ancak mezkur Yönetmelikte maili inhidam tespitlerine ve raporlarına dair herhangi bir belirleme yapılmamıştır.

\subsection{Acil Yıkım Uygulaması}

İș sağlığı ve güvenliği açısından "yıkım işleri (binaların ve diğer yapıların yıkılması ve sökülmesi)" "çok tehlikeli" işler sınıfındadır (URL 17). Her yıkım faaliyetinin bu tehlike sınıfının gerektirdiği hassasiyette iş sağlığı ve güvenliği önlemleri alınarak planlanması gereklidir. Ancak acil yıkım diğer yıkımlara kıyasla daha fazla risklere sahip olduğundan pratikte bu hassasiyetin daha yüksek olması gerektiği açıktır. Bir yapıda deformasyon ve dayanım kaybına yol açan yapısal sorunlar genellikle ani olarak ortaya çıkarak yapıyı riskli hale getirirler. Bu yüzden acil yıkım operasyonlarının hızlı ve güvenli bir şekilde icra edilmesi gerekir. Bir yıkım için en az bir haftalık bir planlama süresi söz konusu olabilirken acil yıkımlarda planlamayı ve gerekli hazırlı̆̆ı yapacak süre ve imkan bulunmaz. Örneğin artçı depremlerin devam ettiği koşullarda acil yıkım gerektiren bir yapının içinde veya dışında yeterli inceleme yapılması mümkün olmaz; asbest gibi tehlikeli kimyasalların mevcudiyeti, yapının bir bütün olarak yapısal stabilitesi vb. temel faktörlere yönelik değerlendirmelerde bulunulmadan yıkıma başlanması gerekebilir. $\mathrm{Bu}$ belirsizlik ve öngörülemezlik durumu acil yıkımları daha riskli hale getirmektedir. Dolayısıyla acil yıkımlar, yıkımda oluşacak riskler hakkında bilgi ve deneyimin ön plana çıktığı; uzmanlık gerektiren özel yıkımlardır.

Acil yıkımların temel önceliği operasyon boyunca güvenliğin korunmasıdır. Özellikle yıkım başlamadan önce çalışanlar mevcut riskler ve risk kontrolünde izlenecek yöntemler konusunda bilgilendirilmelidir. Ayrıca uygun sağlık ve güvenlik şartlarının devamlılığı sağlanmalı; yapılacak risk değerlendirmesi sonucu göre belirlenecek baret, eldiven, toz maskesi vb. kişisel koruyucu malzeme düzenli olarak kullanılmalıdır. Yıkım süresince hem yıkım makinası operatörü hem de sahadaki mühendisler tarafından yapının izlenmesi, faaliyet süresince yapının yüklenmesinden 
(itme, çekme vb.) kaçınılması, yapıdaki yük dağılımının, dolayısıyla yapısal stabilitesinin bozulup bozulmadığının düzenli olarak kontrol edilmesi gerekir. Yıkımın güvenle devam edilebilmesi için yapının etrafındaki bir alan bant vb. ile işaretlenerek giriş çıkışa kapatılmalıdır.

Her yıkımda olduğu gibi acil yıkımlarda da binaya ait elektrik, gaz, su ve iletişim altyapı tesisatının kesilmesine; toz güvenliğine yönelik olarak sabit veya seyyar toz bastırma sistemlerinin kurulmasına; yıkım mahalline giriş çıkışların kontrol altına alınmasına ve özellikle komşu yapılarda oluşabilecek hasarların engellenmesine yönelik önlemler alınmasına önem verilir. Ülkemizdeki binalarda asbestli yapı malzemeleri ile karşılaşılma olasılığı bulunduğundan acil yıkım sürecinde ortama asbest lif salımına yol açmamak için binayı ıslak tutmak çok önemlidir. Acil yıkımlar gece koşullarında yapılması gerekebileceğinden aydınlatma sistemlerinin de yıkım mahallinde bulundurulması gereklidir.

Acil yıkıma konu edilen binanın kat sayısı (bina yüksekliği) arttıkça yıkım riskleri artmaktadır. Acil yıkım operasyonu sırasında olası çökme/göçme riskinden kaçınabilmek için 4-5 katın üzerindeki binaların acil yıkımlarda genellikle uzun erişimli makaslı makinalar tercih edilerek gerekli güvenli çalışma mesafesi oluşturulabilir. Bitişik nizam yapılaşma koşullarında ise komşu mülklere ve çevrede yaşayanlara zarar vermemek için yıkımın belli bir aşamasından sonra makinalı yıkım yerine elle yıkım tercih edilebilir.

Bugün ülkemizde genelde yıkım özelde acil yıkım bağlamında yürütülecek faaliyetlerin güvenlik ve kalitesini yükseltecek teknik bilgi ve prosedürler açık olarak tanımlanmamıştır. Hizmet kalitesi için belirlenmiş gereklilikler olmayınca, bu sürecin sağlıklı bir denetimi ve kontrol sistemi de oluşturulamamıștır. Gelinen noktada acil yıkım faaliyetlerinin teknik boyutunda ülke genelinde uygulama birliğinin sağlandığından söz etmek mümkün değildir.

\subsection{Acil Yıkım Atı̆̆ı Yönetimi}

Ülkemizde afet yönetiminde üzerinde en az araştırma yapılan konulardan biri de afet sonrası ortaya çıkan yıkım atıklarının yönetimidir. Ülkemizde atık yönetiminden ziyade Türkiye Afet Müdahale Planı'nda ifadesini bulan "enkaz yönetim modeli" geçerlidir. Bu model, "enkaz" olarak tanımlanan "afet sonrasında çöken, ağır hasara uğrayan veya tamamen kullanılamaz hâle gelen yapı ve eşya kalıntıları"nın, afet bölgesinden hızla temizlenerek (kaldırılarak) enkaz döküm sahasında bertaraf edilmesine dayanmaktadır (URL 4; Tablo 2). Ancak afet atığının arttığı ve çok yüksek hacimlere ulaştığı günümüzde tek başına "enkaz döküm sahasında bertarafa" dayanan modeller terk edilmiş, geri kazanım odaklı bir afet atığı yönetim modeli benimsenmiştir (URL 18).

Acil yıkım yönetimi atık yönetim literatüründe "inşaat ve yıkıntı atığı (IYYA)" olarak tanımlanan atığın yönetimini de kapsayan bir süreçtir. Ancak bir afet sonrasında ortaya çıkan atıklar sadece IYYA'dan oluşmaz. Çevre ve halk sağlığı açısından tehlike oluşturan enfeksiyöz ve tıbbi atıklar ile tüp gibi patlayıcı atıkları da içerebilir Bu nedenle acil yıkım yönetiminde görev üstlenen kişi ve kurumların yıkımlar sonucu ortaya çıkacak atıklara yönelik planlama ve hazırlıklarını daha önceden yapmaları gerekmektedir. Türkiye Afet Müdahale Planı'nda ise bu hazırlık ve planlama süreci "enkaz döküm alanlarını belirlemekle" sınırlandırılmıştır. Oysa ülkemizde inşaat ve yıkıntı atıklarının yönetimine ilişkin olarak "inşaat/yıkıntı atıklarının geri kazanılması ve özellikle alt yapı malzemesi olarak yeniden değerlendirilmesi" esas alınmış ve "doğal afet atıklarının toplanması, geçici biriktirilmesi, taşınması, geri kazanılması ve bertarafı ile ilgili yönetim planı hazırlamak" görevi Belediyelere verilmiştir (URL 19, Md.5 ve Md.8). Ancak bugüne kadar bu konuda herhangi bir gelişme yaşanmamıștır.

\section{YIKIM SEKTÖRÜ VE ACİL YIKIM}

Günümüzde yıkım, başta $\mathrm{AB}$ ülkeleri olmak üzere dünyanın birçok ülkesinde endüstrinin bir sektörü olarak değerlendirilir (URL 20). Yıkım sektörü aynı zamanda afet müdahale yönetimi 
açısından da önemli bir aktördür. Sahip olduğu makine parkı ve deneyimli insan kaynağı (yıkım mühendisi, operatör, düz işçi, atık yöneticisi, asbest söküm uzmanı vb.) ile yıkım yüklenicisi firmalar hem arama kurtarma aşamasında yıkıntılar arasına sıkışmış afetzedelerin kurtarılmasında hem de çökme/göçme riski taşıyan hasarlı binaların yıkımı ve atıkların kaldırılması hizmetlerini yerine getirirler. Afet sonrası yapılı çevredeki tehlikelerin belirlenmesi sürecinde de görev üstlenebilirler.

Ülkemizde ise ne yıkım iznini veren kamu kurumları ne de bu alanda yüklenici olarak faaliyette bulunan kişi ve kuruluşlar nezdinde yıkım sektörel bir faaliyet olarak görülmez. Meri mevzuatımızda bir binanın nasıl yapılması gerektiğine dair onlarca yönetmelik, standart vb. yer almışken, "bir binanın nasıl yıkılacağına" dair teknik usul ve esasları açıklayan düzenlemeler yok denecek kadar azdır; var olanlar da AB Müktesebatına uyum kapsamında ulusal mevzuatımıza kazandırılmış ancak taraflarca içselleştirilemediğinden yıkım pratiğine tam olarak yansitılamayan kurallar niteliğindedir.

$\mathrm{Bu}$ koşullarda ülkemizde acil yıkım firmalarında işin gerektirdiği ölçüde ve nitelikte bir kurumsallaşmadan bahsetmek oldukça zordur. Yıkımın sektörel bir faaliyet olarak değerlendirilmediği, dolayısıyla firmaların kurumsallaşamadığı koşullarda acil yıkım yönetim sisteminin sağlıklı bir şekilde işletilebilmesi mümkün değildir. Acil yıkım operasyonunun ana aktörlerinden olan yıkım firmalarının yeterli bilgi ve deneyime sahip olması ve bu alanda kurumsallaşmış olması gerekmektedir. Acil yıkıma ne zaman ihtiyaç duyulacağı öngörülemeyeceğinden hızla olay yerine hareket edebilecek, arama-kurtarma ve diğer acil durum ve yerel yönetim birimleriyle uyumlu çalışabilecek, işin doğasındaki risklerin üstesinden gelebilecek düzeyde bilgi birikimine, deneyime ve teknik yeteneğe (personel ve makine altyapısı açılarından) sahip yıkım firmalarına ihtiyaç vardır.

Sahip olduğu özel risklerden dolayı acil yıkım üstlenicisi firmalarının yıkım süresince ortaya çıkabilecek zarar ve hasarı teminat altına alacak sigorta gücünün olması gerekir. Dolayısıyla teknik, sigorta vb. açılardan acil yıkım faaliyetinin, sağlık ve güvenlik gereklerini karşılayacak kapasiteye sahip firmalar dışında diğer firmaların acil yıkım yapması engelleyecek bir yıkım mevzuatına ihtiyaç bulunmaktadır.

\section{DEPREM SONRASI ELAZIĞ İL GENELİNDEKİ ACIL YIKIMLAR}

Ülkemiz jeolojik yapısının bir unsuru olan Doğu Anadolu Fay Zonu (DAFZ) deprem üreten aktif bir faydır. DAFZ'nun Pütürge segmenti üzerinde 24 Ocak 2020 günü yerel saatle 20:55'de Mw=6.8 büyüklüğünde bir deprem meydana gelmiştir. Merkez üssü Elazı̆̆g-Sivrice-Çevrimtaş Köyü olan deprem geniş bir coğrafyada hissedilmiş; başta Elazığ merkez, Sivrice ilçesi ile Malatya-Doğanyol ilçesi olmak üzere birçok yerleşim biriminde hasarlara yol açmıştır. Depremde 41 vatandaşımız hayatını kaybetmiş, 1.631 vatandaşımız yaralanmıştır. Elazı ̆ il genelindeki hasar tespit çalışmaları sonucunda 13800 binanın ağır derecede hasar gördüğü belirlenmiştir.

Depremin hemen sonrasından itibaren afet bölgesinde arama-kurtarma çalışmalarına başlanılmış olup bu çalışmaların tamamlanması ile birlikte bölgede hasar tespit ve beraberinde acil yıkım çalışmalarına geçilmiştir. İlgili kurumlardan alınan bilgilere göre Elazığ il genelinde toplam 1612 adet binanın acil yıkımı yapılmıştır. Elazığ il genelindeki acil yıkımlara ilişkin bilgiler Tablo 3'te sunulmuştur.

Ülkemizde meydana gelmiş afetler/acil durumlar sonrasında gerçekleştirilen acil yıkım faaliyetine yönelik herhangi bir araştırma veya rapor mevcut değildir. Bu açıdan Elazığ Depremi acil yıkım tablosunu geçmiş uygulamalarla kıyaslamak mümkün olamamıştır. Ancak şunu söylemek mümkündür: Elazığ il genelindeki düşük kaliteli yapı stokunun varlı̆gı ile jeolojik koşullar nedeniyle Elazığ depreminin hasar yapıcı etkisi beklenenden çok fazla gerçekleşmiş ve 
Türkiye'de Acil Yıkım Yönetim Sistemi: Temel Yaklaşımlar, Elazığ Deprem Deneyimi Ve Öneriler

yüksek bir acil yıkım tablosu ortaya çıkmıştır. Elazığ'da ağır hasarlı bina yıkımları dahil edildiğinde bu tablonun büyüklüğü daha net anlaşılacaktır.

Tablo 3. Elazı̆̆ Depremi Sonrasında Elazığ İl Genelinde Gerçekleştirilen Acil Yıkım Bina Sayıları

\begin{tabular}{|c|c|c|c|c|}
\hline \multirow[b]{2}{*}{ ACİL YIKIM BÖLGESİ } & \multicolumn{3}{|c|}{ ACİL YIKIMI GERÇEKLEŞTİREN KURUM } & \multirow[b]{2}{*}{ TOPLAM } \\
\hline & $\begin{array}{l}\text { ÇEVRE VE } \\
\text { ŞEHİRCILIIK } \\
\text { BAKANLIĞI }\end{array}$ & $\begin{array}{l}\text { ELAZIĞ İL } \\
\text { ÖZEL } \\
\text { İDARESİ }\end{array}$ & $\begin{array}{l}\text { ELAZIĞ } \\
\text { BELEDİYESİ }\end{array}$ & \\
\hline $\begin{array}{lrl}\text { Elazı } \breve{I} & \text { İ } & \text { Merkezi } \\
\text { (Mahalleler) } & \end{array}$ & 730 & 335 & 54 & 1119 \\
\hline Elazığ İl Merkezi (Köyler) & ---- & 310 & ---- & 310 \\
\hline $\begin{array}{l}\text { Sivrice } \\
\text { (İlçe Merkezi+Köyler) }\end{array}$ & ---- & 210 & ---- & 210 \\
\hline $\begin{array}{l}\text { Elazı̆̆ Diğer İlçeler } \\
\text { (İlçe Merkezi+Köyler) }\end{array}$ & ---- & 44 & ---- & 44 \\
\hline Toplam & 730 & 899 & 54 & 1683 \\
\hline
\end{tabular}

Daha önceki afetlerden sonra acil yıkımlar sadece 7269 sayılı yasanın 13üncü maddesine dayalı yapılırken Elazığ depremi ile birlikte hem afet (7269 sayılı yasa) hem de kentsel dönüşüm (6306 sayılı yasa) hukukuna dayalı acil yıkımlar bir arada gerçekleștirilmiștir. Bu yönüyle Elazı̆̆ Depremi, acil yıkım yönetiminde bir ilk olmuștur. Yine Elazığ depremi, 1999 Depremlerinden sonra, çok geniş alanları ve geniş bir afetzede kitlesini etkileyecek derecede acil yıkımların yapıldığı bir afet olarak da tarihe geçmiştir. Örneğin Mustafa Paşa Mahallesindeki acil yıkım bölgesi 1.798 konutu (bağımsız birimi), Abdullah Paşadaki alan ise 2.225 konutu (bağımsız birimi) kapsamaktadır.

Elazığ depremiyle birlikte acil yıkımlar açısından öne çıkan bir diğer olgu da, acil yıkımların geçmișe kıyasla kentsel bir karakter kazanmıș olmasıdır. Ülkemizde geçmiște meydana gelen afetler sonrasında acil yıkım statüsüne alınmış binalar genellikle 1-2 katlı kerpiç-yığma türü binalar iken, Elazığ depreminde kent merkezindeki 5-10 kat arası binalar acil yıkım statüsüne alınmıştır. Acil yıkımların kentsel alanlarda yoğunlaşması ile birlikte geçmişe kıyasla acil yıkımlardaki hem teknik (karşılaşılan yapısal risklere çözüm üretme, güvenli çalışma mesafesi oluşturma, uzun erişimli makine ihtiyacı, deneyimli işgücü vb.) hem de güvenlik şartlarında niteliksel bir farklılaşma yaşanmıștır. Kentsel alanlarda acil yıkımlar Elazığ kent merkezinde olduğu gibi, aynı andan birkaç noktada birden ve farklı kurumların sevk ve idaresinde acil yıkım yapılıyor olması süreç unsurları arasındaki koordinasyon ihtiyacını öne çıkartmıştır. Kentsel alanlarda gittikçe daha karmaşık ve çok aktörlü bir hale gelen acil yıkım yönetim sistemlerinin artan iş yükü karşısında süreçte coğrafik bilgi sistemleri/kent bilgi sistemlerinin kullanılması önemli hale gelmiştir.

Kentsel karakter acil yıkım yönetimindeki yerel kuruluşların üstlendiği rollerde de bir değişim meydana getirmiştir. Kentsel alanlardaki acil yıkım operasyonları kolluk kuvvetleri ile itfaiyeye çağrı yapılmadan gerçekleștirilememektedir. Elazığ'daki acil yıkımlarda itfaiye yıkımlarda hem toz hem yangın güvenliğinin sağlanması sürecinde, kolluk kuvvetleri ise hem yıkım mahalline giriş çıkışın kontrol edilmesi ve can ve mal güvenliğini sağlanması hem de binalardan eşya ve insan tahliyesinde etkin görevler üstlenmiştir. Hatta kolluk kuvvetlerine o derece ihtiyaç duyulmuştur ki artan talep il dışından geçici görevli gelen emniyet güçlerince karşılanmıştır. Her iki kurum personeli gündüz ve gece devam eden yıkımlarda kesintisiz olarak görev üstlenmiştir. 
Elazığ il genelindeki acil yıkım deneyiminde karşılaşılan bazı sorunlar aşağıda özetlenmiştir;

- Koordinasyon Sorunları: Elazığ ilinde gerçekleştirilen acil yıkımların birbirinden farklı işleyen 2 ayrı acil yıkım prosedürün üzerinden uygulanması ilgili kurumlar ve kamuoyu nezdinde bir algı karmaşası yaratarak afetzedeler arasında "bir çifte standartla karşı karşıya kaldığına" dair değerlendirmeler yapılmasına yol açmıştır. İlde acil yıkım yönetimi için sağlıklı işleyen bir koordinasyon merkezi oluşturulmadığından ilgili kurumlar arasında kopukluklar, yıkım ekiplerinin ve itfaiyenin yönlendirilmesi, teknik altyapının kesilmesi gibi konularda yer yer aksamalar yaşanmıştır. Adrese dayalı bina sorgulama sistemi sağlıklı işlemeyen Elazığ'da acil yıkıma alınan binaların adreslerinin bulunması, tebliğat ve ilan yapılması, binada oturan afetzedelere ulaşılması vb. konularda da sorunlar yaşanmıştır.

- Yıkım Firması Temininde Yaşanan Sorunlar: Deprem sonrasında çok sayıdaki binanın acil yıkım statüsüne alınması nedeniyle acil yıkımın gerektirdiği nitelikte ve kapasitede firma temininde bazı sorunlar yaşanmıştır. Özellikle uzun erişimli (makaslı) yıkım makinası, gece aydınlatma sistemi, su püskürtme gibi ekipmanlar ile deneyimli işgücüne uzun süre ihtiyaç duyulmuş, bu talep il dışından firmalara karşılanmaya çalışılmıştır.

- Halkla İlişkiler Alanında Yaşanan Sorunları: Acil yıkımlara dair yaşanan en önemli sorunlardan biri de halkla ilişkiler alanında yaşanmıștır. Afetzedelerin tahliye ve yıkım konularındaki sorularına yanıt verecek ve ihtiyaç duydukları anda onları bilgilendirecek bir mekanizma sağlıklı olarak işletilememiştir. Yeterli kamuoyu bilgilendirmesinin ve katılımının olmaması, başvuru noktalarının yeterli açıklıkta tanımlanmamış olması hem afetzedeler arasında "umutsuzluk ve karamsarlık" algısının yayılmasina hem de binaların eşyadan ve canlıdan arındırılması süreçlerinde aksamalara yol açmıştır. Eşyalarını kurtarmak için yıkım mahalline gelen afetzedeler ile kamu görevlileri (yıkım denetçileri vb.) arasında yer yer sorunlar yaşanmıştır.

- Yapılı Çevrede Yaşanan Sorunlar: Acil yıkımların yapılı çevre üzerinde neden olduğu en yaygın sorun, yıkılan binaya komşu yapılarda gelișen hasarlar olmuştur. Özellikle Elazığ il merkezindeki bitişik nizam yapı adalarındaki acil yıkımlar komşu binalarda değișik hasarlara neden olmuş; oluşan zararların bir kısmı yıkım firmalarıyla anlaşma yoluyla giderilebilirken bir kısmı ise dava konusu olmuştur. Dar sokaklar ağır iş makinalarının yıkım mahalline ulaşmasını zorlaştırmıştır. Diğer yandan Türkiye Asbest Kontrolü Stratejik Planı kapsamındaki çalışmalarda asbestli toprak bulunduğu belirleniş olan köylerde gerçekleştirilen acil yıkımlarda asbest güvenliğine yönelik yeterli önlemin alınmadığı görülmüştür.

- Sigorta, Yardım vb. İdari ve Hukuki Sorunları: DASK kapsamındaki binaların acil yıkımının sigorta eksperlerinin tespitlerinden önce gerçekleştirilmek zorunda kalınması nedeniyle sigorta eksperleri ile afetzedeler arasında sorunlar yaşanmasına neden olmuştur. Eksperlerin "binanız depremden değil sonra yıkıldı" şeklindeki yaklaşımları afetzedelerin tepkisini çekmiştir. AFAD ve Çevre ve Şehircilik Bakanlığı tarafından kira yardımı, eşya yardımı vb. destek ve yardımlara ilişkin farklı yardım programları açıklanmaları acil yıkımı yapılmış bina sahipleri arasında endişe ve kafa karışıklığı yaratmıştır.

- Atık Yönetimi ve Çevresel Sorunları: Yıkım firmaları tarafından acil yıkımda izlenecek çevresel kriterler belirlenmemiş olduğundan atık yönetimi açısından sorunlar yaşanmıștır. Acil yıkım sonucu ortaya çıkan "İnşaat ve Yıkıntı Atıkları (IYA)" geri kazanımı yapılmadan döküm sahalarına gönderilmiş, enkazdan sadece donatı demiri alınmıştır. Yıkımlar sonucu ortaya çıkan binlerce ton IYA mevcut döküm sahasının kapasitesinin kısa zamanda dolmasına 
Türkiye’de Acil Yıkım Yönetim Sistemi: Temel Yaklaşımlar, Elazığ Deprem Deneyimi Ve Öneriler

neden olmuş, bu nedenle atıkların taşımasında aksamalar yaşanmıştır. Ayrıca atıkların yüklenmesi ve taşınması süreçlerinde de toz, parça düşme gibi sorunlar yaşanmıştır.

\section{SONUÇLAR}

Başta deprem olmak üzere afet tehlikesi yüksek bir coğrafyada kurulu ve yapı stoğu kalitesiz yerleşimlere sahip ülkemizde acil yıkım, merkezi ve yerel yönetimlerin yönetmesi gereken temel bir kamu sağlığı ve güvenliği hizmetidir. Birer risk havuzuna dönüşmüş yerleşimlerimizde aynı anda çok sayıda hasarlı binaya ve bunların yıkım atıklarına müdahale etmek durumunda kalabilecek merkezi ve yerel yönetim birimlerinin bu süreçte başarılı olabilmeleri ve acil yıkımın, bir kamu hizmeti olarak sürdürülebilirliği, en bașta bir yönetim politikası ve modelinin varlığına; ikinci olarak ise hazırlık ve planlanma süreçlerine bağlıdır. Ancak ülkemizde acil yıkımın bir yönetim politikası bulunmamaktadır. Mevcut işleyişin özellikle ardında binlerce yıkık ve ağır hasarlı bina ve milyonlarca ton yıkım atığı bırakacak muhtemel İstanbul depremine yanıt vermesi öngörülmemektedir. Acil yıkım sisteminin, bugüne kıyasla kırsal yerleșim karakterinin daha baskın olduğu ülke koşullarına göre hazırlanmıș, mevcut kentleşme süreçlerini yansıtmaktan uzak, biri (7269 sayılı Kanun) 60 yaşında diğeri (3194 sayılı Kanun) 35 yaşına ulaşmış kanunlarla yönetilmesi mümkün değildir. Diğer yandan 6306 sayılı yasanın yürürlüğe girmesi ile birlikte sürecin hem mevzuat hem kurumsal alt yapısı çok parçalı bir hale gelmiştir. Bu parçalı ve yetersiz bir şekilde işleyen sistemin yeniden yapılandırılması kaçınılmazdır.

Acil yıkım yeni ve günümüz ihtiyaçlarına yanıt verecek şekilde açık bir kavramsal bir çerçeveye oturtulmalı ve sadece afet sonrası değil kamu güvenliği riski taşıyan tekil bazdaki binalar için de izlenmesi gereken Acil Yıkım Raporu ve Bildirimi, Bölge Halkını Bilgilendirme, Yıkım Müteahhidi Atama, Bitişik Mülk Stabilite Değerlendirme, Yıkım Sahası Terk Raporu gibi acil yıkım prosedürleri tanımlanmalıdır. Geliştirilecek teknik, idari, çevresel ve sosyal kılavuzlar ile desteklenecek bu prosedürler, "İl Acil Yıkım Yönetim Planları”, ilgili tüm birimleri koordine edecek yetki tanımlamaları, karar alma, uygulama ve değerlendirme aşamalarında daha etkin bir belediye ve bilgi sistemleriyle ulusal ve il ölçeğindeki yeni acil yıkım yönetim modellerinin özünü oluşturmalıdır.

Bu modellerde hızlı ve doğru karar verme kapasitesini artırmak için coğrafik bilgi sistemleri/kent bilgi sistemleri ile drone görüntüleme sistemi gibi teknikler etkin olarak kullanılmalıdır. Diğer yandan köprü, santral, fabrika gibi birçok kompleks yapılar ile tarihi kültürel değerdeki yapılarda izlenecek acil yıkım prosedürleri de bu yeniden yapılanma sürecinde açıklığa kavuşturulmalıdır. $\mathrm{Bu}$ yeni modelde belediye sınırları içerisindeki acil yıkımlardan Belediyeler, diğer alanlardaki yıkımlardan ise Çevre ve Şehircilik Bakanlığı yetkili ve sorumlu olmalıdır. Bakanlık aynı zamanda hem ülke ölçeğinde acil yıkım yönetim sisteminin izlenmesi ve denetiminden hem de "yerel imkanların yeterli" olduğu seviye hariç diğer afet müdahale süreçlerindeki acil yıkımlardan da sorumlu olmalıdır. Bakanlık ve Belediyeler bünyesinde, genelde yıkım özelde ise acil yıkıma yönelik her türlü işlemden sorumlu "Yıkım Güvenliği Koordinasyon ve Planlama Birim"lerinin oluşturulması yararlı olacaktır.

Türkiye Afet Müdahale Planı (TAMP) yeniden düzenlenerek "acil yıkım" yeni ve temel bir faaliyet olarak tanımlanmalı ve müstakil bir hizmet grubunun görev ve sorumluluğu olarak tanımlanmalıdır. Plan çerçevesinde yürütülecek acil yıkım hizmetlerinde, farklı hizmet gruplarına verilen makine sevk ve kayıt vb. etkinlikleri de kapsayacak şekilde acil yıkımların tüm boyutlarıyla (ilgili kurumlar arası koordinasyon, tahliye, enkaz kaldırma, halkla ilişkiler vb.) bütüncül yönetimi, bu konuda uzman ve tam yetkili bir ekip tarafından üstlenilmesi sağlanmalıdır. Ayrıca TAMP mevzuatı gereğince il ölçeğinde zorunlu tutulan "İl Afet Müdahale Planları" kapsamında gerektiğinde ilçeleri de dikkate alacak şekilde bir "İl Acil Yıkım Yönetim Planı" hazırlanması zorunlu hale getirilmelidir. 
$\mathrm{Bu}$ planların ve acil yıkım yönetimi amacıyla oluşturulacak birimlerin üstlenmesi gereken görevlerden biri de, afet bölgesinin zemin, yapı stoku ve mevcut afet tehlike profiline göre il ölçeğinde acil yıkım senaryolarını hazırlamak ve bu senaryolara uygun olarak emniyet, itfaiye, zabıta, elektrik ve doğalgaz dağıtım şirketleri, su ve kanalizasyon idaresi gibi yerel ölçekteki ilgili kurumlar ile acil yıkım firmalarının katılımıyla planlama ve hazırlıkların yapılması olmalıdır. Acil yıkım karar, koordinasyon, izleme ve kontrol süreçleri coğrafik bilgi sistemleri/kent bilgi sistemleri ve drone görüntülüme sistemleri ile desteklenmelidir.

Acil yıkım yönetimi için yapılması gereken hazırlıkların bir parçasını da Çevre ve Şehircilik Bakanlığı tarafından düzenlenecek acil yıkım başlıklı hizmet içi eğitimler oluşturmalıdır. Türkiye Afet Müdahale Planı kapsamında hasar tespit ekiplerine, yerel yönetim birimlerine ve yıkım firmalarına "acil yıkım" başlıklı eğitimler verilmesi uygun olacaktır.

Acil yıkım faaliyetlerinde görev üstlenecek yıkım firmaları için makine ve personel altyapısı ile deneyim düzeylerine yönelik kriterler tanımlanmalı; yıkım yüklenicisi firmaların hem arama kurtarma hem de acil yıkım aşamalarında üstlenecekleri görevlere uygun niteliklere sahip olması sağlanmalıdır. Her yıkım firmasının acil yıkım yapmasına izin verilmemeli; acil yıkım yapma yeterliliğine sahip yıkım firmaları ayrıca lisanslandırılmalı ve kamuoyuna ilan edilmelidir.

Ülkemizde de İYA ve afet atıklarının hem çevresel etkileri (asbest ve diğer tehlikeli malzemeler vb.) hem de geri dönüşüm potansiyeli göz önüne alınarak yönetilmesi sağlanmalıdır. Acil yıkım sonucu ortaya çıkan atıklar, bina yıkım atıklarına (beton, tuğla, kiremit vb.) ilave olarak mobilya, halı, tüp vb. farklı malzemeleri de içeren bir kompozisyona sahiptir. Bu atıklar taşıdığı ekonomik değer kadar tehlikelilik boyutuyla da değerlendirilerek ayrıştırma ve geri kazanıma tabi tutulmadan bertaraf edilmesi engellenmelidir.

Sosyal boyut ülkemizde acil yıkımda olduğu gibi afet yönetiminin her aşamasındaki faaliyetler için ne yazık ki göz ardı edilen konudur. Yıkılma tehlikesi altında boşaltılan bina sakinlerinin ve/veya afetzedelerin sosyal-psikolojik ihtiyaçlarını karşılayacak, halkla ilişkiler açısından güçlü ve katılımcı modeller ile acil yıkımın sosyal boyutu kesinlikle güçlendirilmelidir.

\section{KAYNAKLAR}

Afetlere İlişkin Acil Yardım Teşkilatı ve Planlama Esaslarına Dair Yönetmelik,1988. R.G:08.05.1988-19808.

Afetlere İlişkin Acil Yardım Teşkilâtı ve Programları Hakkında Yönetmelik,1968. R.G:12.09.1968-12999.

ERSÖZ, A.K,2015. Bir İdari İşlem Olarak Yıkım Kararı, Gazi Üniversitesi Hukuk Fakültesi Dergisi C. XIX, Y. 2015, Sa.3.

URL 1, (New Urban Agenda, United Nations)

http://habitat3.org/wp-content/uploads/NUA-English.pdf (Son Erişim: 03.07.2020)

URL 2, http://ohrules.elaws.us/oac/3745 (Ohio Administrative Code (OAC), Chapter 3745-20. Ohio Environmental Protection Agency İnstructions For Completing Notification Of Demolition And Renovation Form) (Son Erişim: 03.07.2020)

URL 3, (Anayasa Mahkemesi Esas Sayısı:2015/77, Karar Sayısı: 2015/73)

https://www.anayasa.gov.tr/Kararlar/GenelKurul/Basvuru_Karari/2015-73.pdf (Son Erişim: 02.07.2020)

URL 4, https://www.afad.gov.tr/aciklamali-afet-yonetimi-terimleri-sozlugu (Son Erişim: 02.07.2020) 
Türkiye'de Acil Yıkım Yönetim Sistemi: Temel Yaklașımlar, Elazı̆̆ Deprem Deneyimi Ve Öneriler

URL 5, Umumi Hayata Müessir Afetler Dolayısıyla Alınacak Tedbirlerle Yapılacak Yardımlara Dair Kanun (7269),1956.

https://www.mevzuat.gov.tr/mevzuat?MevzuatNo=7269\&MevzuatTur=1\&MevzuatTertip=3 (Son Erişim: 03.07.2020)

URL 6, https://www.resmigazete.gov.tr/eskiler/2013/12/20131218-13.htm (Son Erişim: 03.07.2020)

(Afet ve Acil Durum Müdahale Hizmetleri Yönetmeliği, 2013. R.G:18.12.2013-28855)

URL 7, https://www.resmigazete.gov.tr/eskiler/2014/01/20140103-12.htm (Son Erişim: 03.07.2020)

(Türkiye Afet Müdahale Planı (TAMP), 2014. R.G:03.01.2014-28871)

URL 8, https://www.resmigazete.gov.tr/arsiv/1471.pdf

Belediye Kanunu (1580),1930. R.G:14.04.1930-1471.

URL 9, https://kms.kaysis.gov.tr/Home/Detay/47315

Belediye Yapı Ve Yollar Kanunu (2290),1933. R.G:21.06.1933-2433

URL 10, https://kms.kaysis.gov.tr/Home/Detay/49112 (Son Erişim: 03.07.2020)

URL 11, https://www.mevzuat.gov.tr/mevzuat?MevzuatNo=3194\&MevzuatTur=1\&MevzuatTertip=5 (Son Erişim: 03.07.2020)

URL 12, https://www.kayseri.bel.tr/uploads/yonetmelikler/13249 yonetmelik.pdf (Son Erişim: 02.07.2020)

URL 13,

https://www.mevzuat.gov.tr/mevzuat?MevzuatNo=11244\&MevzuatTur=7\&MevzuatTertip=5

Erişim: 02.07.2020)

URL 14, (Afet Riski Altındaki Alanların Dönüștürülmesi Hakkında Kanun) https://www.mevzuat.gov.tr/mevzuat?MevzuatNo=6306\&MevzuatTur=1\&MevzuatTertip=5 (Son Erişim: 01.07.2020)

URL 15,

https://www.danistay.gov.tr/upload/yayinlar/20 05 2019 042653.pdf (Son Erişim: 03.07.2020)

URL 16, (Koruma, Uygulama Ve Denetim Büroları, Proje Büroları İle Eğitim Birimlerinin Kuruluş, İzin, Çalışma Usul Ve Esaslarına Dair Yönetmelik)

https://www.mevzuat.gov.tr/mevzuat?MevzuatNo=8323\&MevzuatTur=7\&MevzuatTertip=5 (Son Erişim: 03.07.2020)

URL 17, (İş Sağlı̆̆ı Ve Güvenliğine İlişkin İşyeri Tehlike Sınıfları Tebliği)

https://www.resmigazete.gov.tr/eskiler/2012/12/20121226-11.htm (Son Erişim: 03.07.2020)

URL 18, https://www.unocha.org/sites/unocha/files/DWMG.pdf (Son Erişim: 03.07.2020)

(Disaster Waste Management Guidelines, United Nations Office For The Coordination Of Humanitarian Affairs Environmental Emergencies Section)

URL 19, (Hafriyat Toprağı, İnşaat Ve Yıkıntı Atıklarının Kontrolü Yönetmeliği)

https://www.mevzuat.gov.tr/mevzuat?MevzuatNo=5401\&MevzuatTur=7\&MevzuatTertip=5 (Son Erişim: 02.07.2020)

URL 20, (European Demolition Association)

https://www.europeandemolition.org/industry/presentation/ (Son Erişim: 01.07.2020)

Yersarsıntısından Evvel Ve Sonra Alınacak Tedbirler Hakkında Kanun (YESATHK), Resmi Gazete: 22.07.1944-5763. 